\title{
Procedural safety and short-term outcome in Asian men treated with magnesium bio-resorbable scaffold
}

Background: Bioresorbable scaffold offer the advantages of reduced long-term complications such as stent fracture, late stent thrombosis and in-stent restenosis as well as the return of normal vasomotor function and late lumen gain with plaque regression.

Objective: Identify safety and outcomes of patients undergoing percutaneous coronary intervention $(\mathrm{PCl})$ with magnesium BRS.

Materials and methods: This was a prospective, observational single centre study conducted in UiTM Sungai Buloh from $1^{\text {st }}$ November 2016 to $14^{\text {th }}$ February 2017.

Results: 7 patients were enrolled. The mean age was $46 \pm 9$. All patients were male. Ethnicity breakdown showed 5 Malays, 1 Chinese, and 1 Indian. Cardiovascular risk assessment revealed $85.7 \%$ diabetes mellitus, $42.9 \%$ smokers, $28.6 \%$ hypertension and $28.6 \%$ dyslipidaemia. Target vessels treated were 6 left anterior descending (LAD) and 1 right coronary artery (RCA). Out of the 7 patients, $28.6 \%$ were type A lesions, $42.8 \%$ were type $B$, and $28.5 \%$ were type $C$. Among those lesions, 3 involved LAD-D1 bifurcations, and 2 were total occlusions. The lesions were prepared with semi-compliant balloons in 5 cases and non-compliant balloons in 2 cases. The balloon-to-stent ratios were 1:1 $(n=1), 0.92: 1(n=1), 0.85: 1(n=4)$ and 0.83:1 $(n=1)$. The magnesium BRS diameters used were $3.5 \mathrm{~mm}(n=4)$ and $3.0 \mathrm{~mm}(n=3)$ with length of $15 \mathrm{~mm}(n=1), 20 \mathrm{~mm}$ $(n=4)$ and $25 \mathrm{~mm}(\mathrm{n}=2)$. Post-dilatation in one patient was carried out with non-compliant balloon of equal diameter to the stent, while the rest had upsizing with $+0.5 \mathrm{~mm}$ larger non-compliant balloon. Procedural outcome was $100 \%$ successful. At three-month follow-up, there were no symptoms, MACE or TLR.

Conclusion: We demonstrated safety and good short-term outcome in the use of magnesium BRS in our cohort, including stenting of total occlusions as well as bifurcation lesions. A larger cohort and longer-term outcome would better delineate the safety and efficacy of this new technology in treating coronary artery disease.

Keywords: Magnesium based bioresorbable scaffold (BRS), Magnesium BRS, Magmaris bioresorbable scaffold, Asian short-term outcome, Procedural safety

\section{Introduction}

Invasive coronary angiography remains the gold standard investigation for high definition coronary artery anatomy assessment [1]. The forefront of coronary artery disease treatment was the Vineberg procedure [2-5], even before the advent of coronary angiography [6-8]. Treatments of coronary stenosis have evolved from the use of balloon angioplasty in 1977 to the use of bare-metal stent (BMS) in 1986 [9-15]. Issues with recurrence of restenosis at the site of implantation lead to the advent of paclitaxel and sirolimus coating drug eluting stents (DES), with the former being less favoured due to higher complication rates such as late in-stent thrombosis (IST) [16-23].
Nicholas Chua Yul Chye ${ }^{1 *}$, Mohd Kamal Mohd Arshad', Rizmy Najme Khir ${ }^{1}$, Lim Chiao Wen', Johan Rizwal Ismail', Effarezan Abdul Rahman', Hafisyatul Aiza', Khairul Shafiq Ibrahim', Abdul Wahab Undok², Zubin Othman Ibrahim', Sazzli Kasim¹,3 ${ }^{1}$ Cardiology Unit, Medical Department of Universiti Teknologi MARA (UiTM) Sungai Buloh, Malaysia ${ }^{2}$ Cardiology, KPJ Rawang Specialist Hospital, Malaysia

${ }^{3}$ Institute for Pathology, Laboratory and Forensic Medicine (I-PPerForM), Malaysia *Author for correspondence:

Tel: +60123520036

E-mail: yulchye@gmail.com Submitted: June 04, 2017 Accepted: July 11, 2017 Published online: July 18, 2017 
The treatment of coronary stenosis escalated with percutaneous coronary intervention (PCI) being favoured over bypass surgery in most cases with low SYNTAX (Taxus drug-eluting stent versus coronary artery bypass surgery for the treatment of narrowed arteries) scores [24-28]. With greater usage, issues with DES emerged such as late in-stent thrombosis (IST) and in-stent restenosis (ISR) [29]. Polymers coating the stents that are necessary for drug delivery are now known to be a cause of localised vessel inflammation, risking inadequate healing and stent thrombosis [30-33]. The loss of vasomotor function associated with inadequate healing is also associated with the permanent nature of the metal scaffold and this is more evident with sirolimus-eluting stents [34-38]. These issues gave rise to the need to treat coronary stenosis without leaving a permanent 'cage' to the vessel [39].

The first polymer bioresorbable scaffold (BRS) Absorb (Abbott Vascular, Santa Clara, CA) was introduced in 2011 [40]. Patients treated with Absorb were compared to a conventional DES (Xience) and found to have twice the risk of definite or probable scaffold thrombosis at one year [41,42]. Subgroup analysis in ABSORB-III illustrated that Absorb implanted in smaller vessel diameter $(<2.63$ $\mathrm{mm}$ ) had a higher 1-year rate of device thrombosis compared to Xience $(2.3 \%$ vs. $0.9 \%$; relative risk ratio: 2.65) [43]. The Absorb stents were bulky and less able to negotiate difficult tortuosity found in many coronaries due to its inherent polymer design [44]. This lead to the development of metallic based absorbable stent.

Second-generation magnesium BRS, Magmaris was released last year by Biotronik with early promising results in European patients. The magnesium alloy scaffold is coated with sirolimus eluting drug and bioabsorbable poly-L- lactide (PLLA) polymer matrix coating [45-54].

\section{Materials and Methods}

This was a prospective, single centre observational study conducted in Universiti Teknologi MARA Medical Centre (PPUiTM), Malaysia from 1st November 2016 to 14th February 2017. All patients who underwent percutaneous coronary intervention (PCI) with magnesium based BRS were recruited. Percutaneous coronary intervention was performed according to standard practices. Consent was obtained from all patients prior to procedure.

Data collected were patient demographics, anthropometry, cardiovascular risk factors, laboratory results, echocardiography, coronary angiographic findings, Syntax score, procedural details and procedural outcome. The primary end points recorded at 30 and 90 days were symptoms, target lesion revascularization (TLR), target lesion failure (TLF) and mortality. Target lesion failure is defined as composite of cardiac death not clearly attributed to a vessel other than the target vessel, target vessel myocardial infarction (MI) and ischaemia driven target lesion revascularization (TLR).

\section{Results}

7 patients were recruited during the study period. The mean age was $46 \pm 9$ years old and all were men. The gender recruitment was by chance and the Malaysian National Cardiovascular Disease (NCVD) Acute Coronary Syndrome registry illustrated a male dominance of $79.4 \%$ in 2013 [55]. Ethnicity breakdown revealed 5 Malays, 1 Chinese and 1 Indian. The mean body mass index (BMI) was $27.8 \pm 2.9 \mathrm{~kg} / \mathrm{m}^{2}$. The indication for revascularization were due to ST-elevation myocardial infarction (STEMI, $\mathrm{n}=4$ ), unstable angina $(\mathrm{UA}, \mathrm{n}=2)$ and non-ST elevation myocardial infarction (NSTEMI, $n=1$ ). Cardiovascular risk factors illustrated $85.7 \%$ diabetes mellitus, $42.9 \%$ cigarette smokers, $28.6 \%$ hypertension and $28.6 \%$ dyslipidaemia. Mean left ventricular ejection fraction (LVEF) by modified Simpsons biplane method was $49 \pm 8 \%$. Coronary angiography was performed with a mean SYNTAX score of 16 \pm (Min 3, Max 33) (Table 1).

Target vessels treated were 6 left anterior descending (LAD) arteries and 1 right coronary artery (RCA). Out of the 7 patients, $28.6 \%$ were type A lesions, $42.8 \%$ were type $\mathrm{B} 1$, and $28.5 \%$ were type $\mathrm{C}$. Among those lesions, 3 involved LAD-D1 bifurcations, and 2 were total occlusions. All patients had non-calcified lesions. The lesions were prepared with semi-compliant balloons in 5 cases and non-compliant balloons in 2 cases. The balloonto-stent ratios were 1:1 $(\mathrm{n}=1), 0.92: 1(\mathrm{n}=1), 0.85: 1(\mathrm{n}=4)$ and 0.83:1 ( $\mathrm{n}=1)$. The magnesium BRS diameters used were $3.5 \mathrm{~mm}(\mathrm{n}=4)$ and $3.0 \mathrm{~mm}(\mathrm{n}=3)$ with lengths of 15 $\mathrm{mm}(\mathrm{n}=1), 20 \mathrm{~mm}(\mathrm{n}=4)$ and $25 \mathrm{~mm}(\mathrm{n}=2)$.

All percutaneous coronary interventions were performed via right radial artery access. Guiding catheters used were 6-French EBU 3.5 (Extra Backup, Medtronic. $\mathrm{n}=6$ ) and 6-French JR 3.5 (Judkins Right, Terumo. $\mathrm{n}=1$ ). Mean contrast volume was $204 \pm 90 \mathrm{ml}$ and mean radiation dose was $3604 \pm 1737 \mathrm{mGy}$. Three patients had multi-vessel PCI. Post-dilatation in one patient was carried out with non-compliant balloon of equal diameter to the stent, while the rest had upsizing with $+0.5 \mathrm{~mm}$ larger non-compliant balloon. Magnesium BRS procedural implantation success 
Table 1: Patients baseline parameters.

\begin{tabular}{|cccccccccccc|}
\hline Patient & Age & BMI & Sex & Indication & HTN & DM & Dyslipidemia & Smoker & eGFR & Creatinine & LVEF \\
\hline 1 & 59 & 28.1 & M & UA & N & Y & Y & N & 81 & 89 & 54 \\
\hline 2 & 37 & 25.7 & M & STEMI & N & Y & N & Y & 111 & 73 & 59 \\
\hline 3 & 53 & 32.4 & M & STEMI & Y & Y & Y & N & 93 & 80 & 45 \\
\hline 4 & 55 & 27.6 & M & UA & Y & Y & N & N & 76 & 95 & 54 \\
\hline 5 & 45 & 23.7 & M & STEMI & N & Y & N & N & 90 & 85 & 38 \\
\hline 6 & 43 & 26.4 & M & STEMI & N & Y & N & Y & 88 & 87 & 42 \\
\hline 7 & 35 & 30.6 & M & NSTEMI & N & N & N & Y & 99 & 82 & 51 \\
\hline
\end{tabular}

(Y:Yes; N: No; BMI: Body Mass Index; M: Male; HTN: Hypertension; DM: Diabetes Mellitus; eGFR: estimated glomerular filtration rate in $\mathrm{mL} / \mathrm{min} / 1.73 \mathrm{~m}^{2}$, LVEF: Left Ventricular Ejection Fraction in \%)

rate was $100 \%$ with no complications or technical difficulties. There was no residual stenosis at the stented segments in all patients (Table 2).

Post procedure, all patients were discharged the following day and planned for 12 months of dual antiplatelet therapy with $75 \mathrm{mg}$ of aspirin and 75 mg of clopidogrel daily. At 30-days and 90-days post procedure, there were no symptoms, target lesion revascularisation (TLR), target lesion failure (TLF) or mortality (Table 3).

\section{Discussion}

\section{First-generation magnesium BRS (DREAMS I)}

Drug eluting absorbable metal scaffold (DREAMS) was based on absorbable metal stent (AMS-2, Biotronik) platform, which consists of magnesium scaffold backbone, degradable polymer and paclitaxel elution. It has a strut thickness of $125 \mu \mathrm{m}$ and uses platinum radio-opaque markers. DREAMS provide scaffolding and paclitaxel release up to 3 months. In comparison to Taxus (Boston Scientific), DREAMS illustrated comparable in vitro elusion and late lumen loss, but with lower inflammatory scores. that demonstrated TLF of $6.8 \%$ at 12 months, which comprised of $2.3 \%$ target-vessel myocardial infarction (TV-MI), $4.5 \%$ clinically driven target lesion revascularization (cdTLR) and no cardiac deaths [57,58].

\section{Second-generation magnesium BRS (DREAMS II, Magmaris)}

Magmaris scaffold backbone is comprised of

Table 2: Patient Coronary Characteristics (LAD=left anterior descending, RCA=right coronary artery).

\begin{tabular}{|cccccccccc|}
\hline Patient & $\begin{array}{c}\text { Target } \\
\text { Vessel }\end{array}$ & $\begin{array}{c}\text { SYNTAX } \\
\text { Score }\end{array}$ & $\begin{array}{c}\text { Proximal } \\
\text { Reference } \\
\text { Diameter, } \mathbf{m m}\end{array}$ & $\begin{array}{c}\text { Distal } \\
\text { Reference } \\
\text { Diameter, } \mathbf{m m}\end{array}$ & $\begin{array}{c}\text { Lesion } \\
\text { Length, } \\
\mathbf{m m}\end{array}$ & $\begin{array}{c}\text { Lesion } \\
\text { Stenosis, } \\
\%\end{array}$ & $\begin{array}{c}\text { Bifurcation, } \\
\text { Medina }\end{array}$ & $\begin{array}{c}\text { Total } \\
\text { Occlusion }\end{array}$ & $\begin{array}{c}\text { Lesion } \\
\text { Type }\end{array}$ \\
\hline 1 & LAD & 14 & 4.0 & 3.4 & 12 & 70 & $1,1,1$ & $\mathrm{~N}$ & $\mathrm{~B} 1$ \\
\hline 2 & RCA & 3 & 3.5 & 3.0 & 20 & 60 & $\mathrm{~N}$ & $\mathrm{Y}$ & $\mathrm{C}$ \\
\hline 3 & LAD & 16 & 3.5 & 3.5 & 10 & 80 & $\mathrm{~N}$ & $\mathrm{~N}$ & $\mathrm{~B} 1$ \\
\hline 4 & LAD & 19 & 3.5 & 3.0 & 14 & 70 & $\mathrm{~N}$ & $\mathrm{~N}$ & $\mathrm{~A}$ \\
\hline 5 & LAD & 10 & 4.0 & 3.5 & 8 & 70 & $\mathrm{~N}$ & $\mathrm{~N}$ & $\mathrm{~A}$ \\
\hline 6 & LAD & 33 & 3.0 & 2.75 & 20 & 90 & $1,1,1$ & $\mathrm{Y}$ & $\mathrm{C}$ \\
\hline 7 & LAD & 19 & 3.0 & 3.0 & 8 & 95 & $1,1,1$ & $\mathrm{~N}$ & $\mathrm{~B} 1$ \\
\hline
\end{tabular}

Table 3: Patients PCI Procedural Information.

\begin{tabular}{|c|c|c|c|c|c|c|c|c|c|c|}
\hline Patient & $\begin{array}{l}\text { Guiding } \\
\text { Catheter }\end{array}$ & SC & NC & $\begin{array}{l}\text { Pre-dilatation } \\
\text { Balloon } \\
\text { Diameter, mm }\end{array}$ & $\begin{array}{c}\text { BRS } \\
\text { Diameter, } \\
\text { mm }\end{array}$ & $\begin{array}{c}\text { BRS } \\
\text { length, } \\
\text { mm }\end{array}$ & $\begin{array}{l}\text { Post-dilatation } \\
\text { NC Balloon } \\
\text { Diameter }\end{array}$ & $\begin{array}{c}\text { Radiation, } \\
\text { mGy }\end{array}$ & $\begin{array}{c}\text { Fluoro } \\
\text { Time, } \\
\text { min }\end{array}$ & $\begin{array}{c}\text { Contrast, } \\
\mathrm{ml}\end{array}$ \\
\hline 1 & 6Fr EBU3.5 & $\mathrm{Y}$ & $\mathrm{N}$ & 3.5 & 3.5 & 20 & 4.0 & 3758 & 33 & 110 \\
\hline 2 & 6Fr JR3.5 & Y & $\mathrm{N}$ & 3.0 & 3.0 & 25 & 3.5 & 2644 & 13 & 100 \\
\hline 3 & 6Fr EBU3.5 & $\mathrm{Y}$ & $\mathrm{N}$ & 3.0 & 3.5 & 20 & 4.0 & 3170 & 25 & 210 \\
\hline 4 & 6Fr EBU3.5 & $\mathrm{Y}$ & $\mathrm{N}$ & 3.0 & 3.5 & 20 & 3.5 & $5057^{*}$ & 27 & $270^{*}$ \\
\hline 5 & 6Fr EBU3.5 & $\mathrm{N}$ & $\mathrm{Y}$ & 3.0 & 3.5 & 20 & 4.0 & 1375 & 16 & 150 \\
\hline 6 & 6Fr EBU3.5 & $\mathrm{N}$ & $\mathrm{Y}$ & 2.5 & 3.0 & 25 & 3.5 & $2633^{*}$ & 22 & $240^{*}$ \\
\hline 7 & 6Fr EBU3.5 & $Y$ & $\mathrm{~N}$ & 2.75 & 3.0 & 15 & 3.5 & $6597^{*}$ & 84 & $350^{*}$ \\
\hline
\end{tabular}

(SC: Semi-compliant; NC: Non-compliant; EBU: Extra Back-up Guiding Catheter; JR: Judkins Right Guiding Catheter; Patients 4, 6 and 7 had multi-vessel $\mathrm{PCl}$ ) 
magnesium alloy and $95 \%$ of magnesium is absorbed at 12 months. The scaffold has a strut thickness of $150 \mu \mathrm{m}$ and is laser-polished, giving rise to its very smooth surface. Aiding visualization and placement are two radiopaque tantalum markers at the scaffold edges. It is available in two diameters of $3.0 \mathrm{~mm}$ and $3.5 \mathrm{~mm}$, and three lengths of $15 \mathrm{~mm}, 20 \mathrm{~mm}$ and $25 \mathrm{~mm}$. Its polymer coating and drug is identical to Orsiro DES (Biotronik), which comprised of sirolimus with bioabsorbable poly-L-lactide (PLLA) polymer matrix coating [59]. BIOSOLVE-II was a multicentre, non-randomized, first-in-man trial with a total of 123 patients implanted with Magmaris. Long-term safety showed target lesion failure (TLF) of $3.3 \%$ at six months, which comprised of $0.8 \%$ cardiac death, $0.8 \%$ target vessel MI and $1.7 \%$ clinical driven TLR. Of note, no stent thrombosis was observed at 12 months [60-62]. BIOSOLVE-II and BIOSOLVE-III pooled 24 months outcome revealed TLF of $3.3 \%, 3.4 \%$ and $5.9 \%$ at 6,12 and 24 months, respectively. Throughout the 24-month period, there was no definite or probable scaffold thrombosis [60-62].

\section{Magnesium metabolism}

Magnesium is the fourth most abundant cation in the body. It is a prominent intracellular cation required for the function of hundreds of enzyme systems. Magnesium blood serum concentration is $1.7-2.6 \mathrm{mg} /$ $\mathrm{dl}$ and its level is regulated by the intestines, kidneys and bones [63-65]. Magnesium scaffold interacts with water to form magnesium hydroxide and hydrogen. One Magmaris BRS has approximately $8.5 \mathrm{mg}$ of magnesium and $95 \%$ is resorbed over 12 months. After resorption of magnesium BRS scaffold, intravascular ultrasound (IVUS) and optical coherence tomography
(OCT) have shown that the scaffold space was replaced with calcium apatite complex and accompanied by a phosphorous compound [66].

\section{Magnesium and endothelium}

Magnesium promotes re-endothelialisation via increasing migration and proliferation of endothelial cells. The role of magnesium in prevention of thrombosis is through reduction of cleavage of ultralarge von Willebrand Factor (vWF), hence reducing platelet adhesion and aggregation. Reduction of free radicals and nuclear factor kappa-light-chain-enhancer of activated B cells (NF-kB) both reduces local inflammation at the scaffold [67-69].

\section{Magnesium and vascular smooth muscle}

Magnesium promotes vasodilatation via attenuation of vasoconstrictor action and inhibition of calcium transport. Magnesium act pharmacologically as noncompetitive antagonist of $\mathrm{N}$-methyl-D-aspartate (NMDA) receptor by virtue of their role as endogenous voltage-sensitive blockers of the ion channel. It also reduces neointima formation by reducing extracellular matrix (ECM) synthesis and cellular migration [70,71].

\section{Advantages of polymer BRS}

The absence of residual metallic foreign body reduces long-term complications such as stent fracture, late stent thrombosis and in-stent restenosis. Late lumen gain is seen with plaque regression. Absence of scaffold allows restoration of physiological vasomotor function and reduction of dual antiplatelet therapy duration [60-62]. Late advantages are ability for future noninvasive cardiac imaging with modalities like multi-slice computed tomography (MSCT) and cardiac magnetic resonance imaging (CMR) (Figure 2).

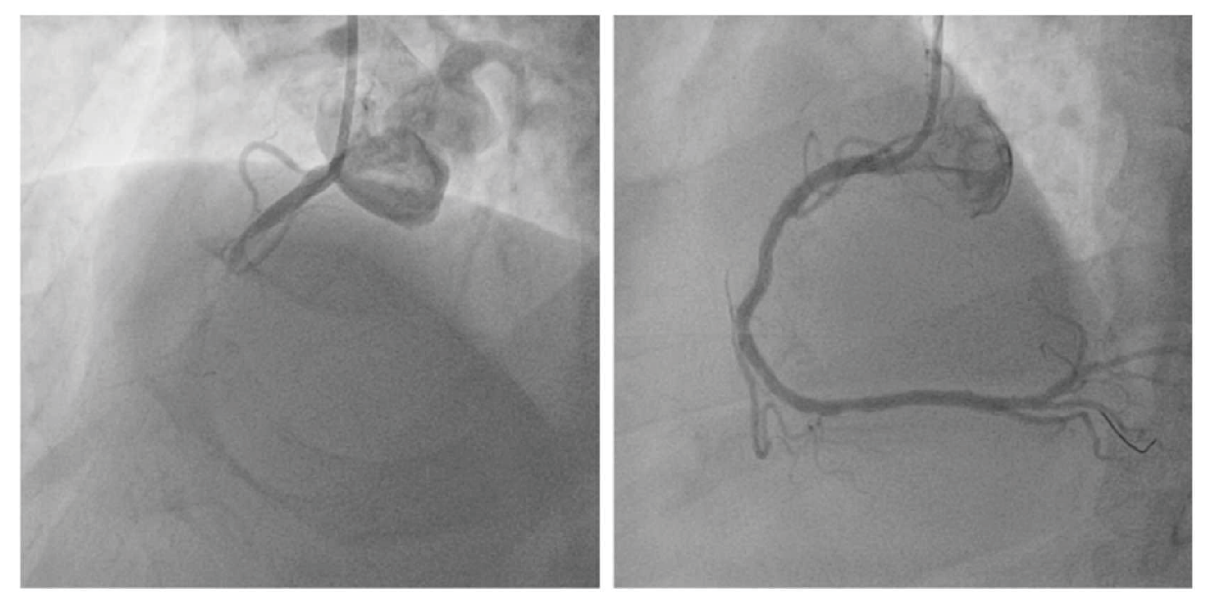

Figure 1: A 37-year-old gentleman with inferior myocardial infarction (7 days post Ml with Streptokinase). Treated with Magmaris $3.0 / 25$ and post-dilated with $3.5 \mathrm{NC}$. 

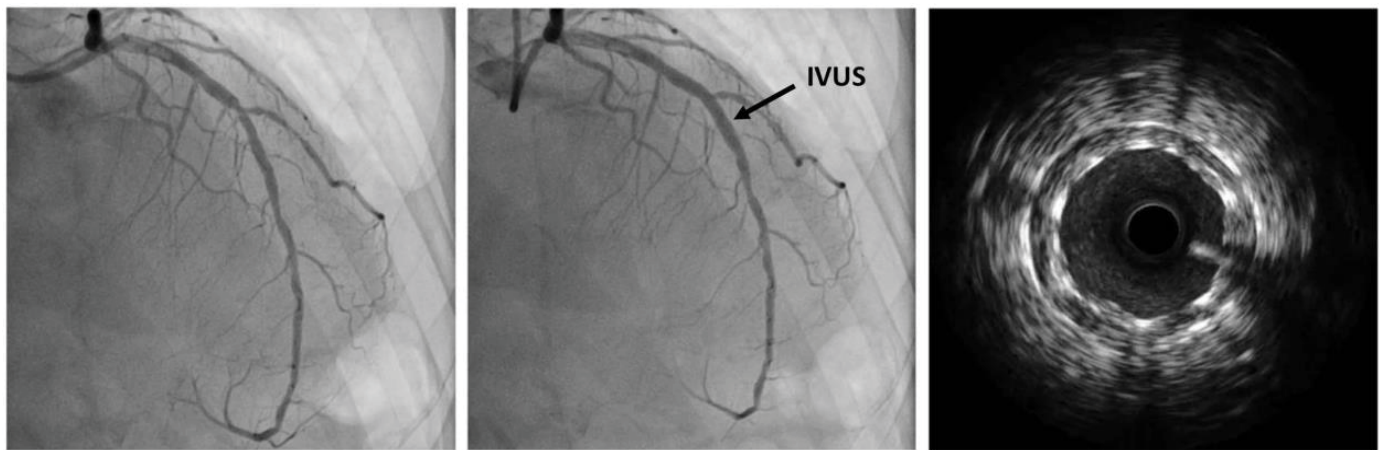

Figure 2: A 60-year-old gentleman with unstable angina. Treated with Magmaris 3.5/20 and post-dilated with 4.0 NC balloon. Intravascular Ultrasound (IVUS) showed good scaffold apposition and no edge dissection or thrombus.

\section{Limitations of polymer BRS}

There are several limitations of polymer based BRS. Polymer scaffold struts are thicker, for instance 157 $\mu \mathrm{m}$ in Absorb PLLA-EES and $165 \mu \mathrm{m}$ in DeSolve PLLA-NOV. Thicker struts makes the scaffold less deliverable and its polymer nature makes it slow to expand during implantation [72]. Apart from being prone to fractures, polymer BRS also has limited use in bifurcations, calcified, long or diffusely disease lesions. It also requires refrigeration during storage. PLLA scaffold has cautionary use in small vessels. However, it was observed that Absorb implanted in vessels bigger than $2.63 \mathrm{~mm}$ had no difference in device thrombosis at 1 -year compared to Xience $(0.8 \%$ vs. $0.6 \%$; relative risk ration: 1.28) [43].

\section{Advantages of metallic BRS}

Magnesium scaffold bio-absorb within 6 to 12 months, and this potentially reduces the duration of dual antiplatelet therapy and late complications of residual metallic cage seen in BMS and DES. Metallic BRS has comparable radial force to stainless steel and cobalt chromium stents. The crimped profile of Absorb was $1.38 \pm 0.01 \mathrm{~mm}$, while the Magmaris was $1.44 \pm 0.00 \mathrm{~mm}$ and in vitro study has demonstrated superior tractability and force transmission of the latter [73]. Intravascular ultrasound (IVUS) sub-analysis in BIOSOLVE II revealed that the loss in minimum lumen area (MLA) at 6 months with Magnesium $\left(-0.83 \mathrm{~mm}^{2}\right)$ is related to a reduction in the minimum scaffold area $\left(-0.79 \mathrm{~mm}^{2}\right)$ rather than neointimal area $\left(0.08 \mathrm{~mm}^{2}\right)$. Comparison in paired patient illustrated scaffold area remain the same between 6 and 12 months [60,61,7476]. Sirolimus-eluting Magmaris offers radial support for 3 to 6 months and has a degradation time of 9 months [77]. The dissolution of scaffold leads to formation of inorganic salts, which produce electronegative charge with antithrombotic effect $[78,79]$.

\section{Disadvantages of metallic BRS}

Several disadvantages of resorbable metallic scaffold are time of degradation, rate of degradation, remaining polymer, biocompatibility, drug elution, scaffolding and radial force, early and late recoil, and poor radioopacity of scaffold $[78,79]$.

\section{Other Bioresorbable Scaffolds:}

\section{Absorbable metal stent}

Absorbable metal stent (AMS, Biotronik, Berlin, Germany) was the first metallic bioresorbable scaffold. First generation non-drug eluting AMS was composed of high strength WE43 magnesium alloy with a strut thickness of $165 \mu \mathrm{m}$ [80]. The radial strength of scaffold is similar to that of metallic stent with low elastic recoil $(<8 \%)$, high collapse pressure $(0.8 \mathrm{Bar})$ and minimal shortening after inflation $(<5 \%)$ [81]. Early studies illustrated degradation into inorganic salts within 60 days $[82,83]$. AMS was an evolution of Lekton Magic stents (Biotronik), which were first evaluated in porcine coronary artery and followed by human lower limb [84].

\section{Igaki-Tamai BRS}

This was the first fully bioresorbable stent evaluated in man. Igaki-Tamai scaffold (Kyoto Medical, Japan) was made of PLLA without any drug coating and has a strut thickness of $170 \mu \mathrm{m}$. The first-generation scaffold was both thermal self-expanding and balloon expandable. In IVUS analysis, the stent struts mostly disappeared within 3 years. Nishio et al. reported 38\% TLR at 10 years follow-up [85]. Igaki-Tamai BRS was challenging to use as it required heated contrast and large 8-French guide catheter. Newer revisions are currently being evaluated.

\section{DESolve BRS}

DESolve BRS (Elixir Medical, CA, USA) has a PLLA 
scaffold and is coated with novolimus. It has a strut thickness of $150 \mu \mathrm{m}$ and resorbs in 2 years. The scaffold has sinusoidal ring patterns and good radial strength. Newer generation DESolveNX and DESolve100 have thinner struts $(120 \mu \mathrm{m}) .2$ year DESolve outcome trial with 126 patients illustrated major adverse cardiac event rate of $3.3 \%(n=4$ of 122$)$ at 6 months and $7.4 \%$ $(\mathrm{n}=9$ of 122$)$ at 24 months, including 1 probable stent thrombosis within the first month. Optical coherence tomography analysis during 6-month follow-up, showed full strut coverage in $99 \pm 1.7 \%[86,87]$.

\section{Fortitude, aptitude and magnitude}

Several iterations of sirolimus coated polymer bioresorbable scaffold were developed by Amaranth Medical Inc, Mountain View, CA, USA. The PLLA scaffold is made of multiple layers of high molecular weight semi-crystalline polymers to provide superior flexibility and strength. The structural integrity of the Amaranth scaffold lasts 3 to 6 months. The FORTITUDE $(150 \mu \mathrm{m})$, APTITUDE $(120 \mu \mathrm{m})$ and MAGNITUDE $(90 \mu \mathrm{m})$ scaffolds have various strut thickness. The FORTITUDE was investigated in MEND II and RENASCENT-I studies. Nine-month follow-up in 45 patients showed 2.2\% TLF [88-92].

\section{MeRes BRS}

MeRes BRS (Meril Life Sciences, Vapi, Gujarat, India) is a merilimus eluting bioresorbable coronary scaffold. The scaffold backbone comprised of PLLA polymer with a top coat of poly (D,L-lactic acid) (PDLLA), which controls the release of drug. Its strut thickness is $100 \mu \mathrm{m}$ and it has uniquely differentiated triaxial-couplets platinum radio-opaque markers that provide greater visibility during deployment. MeRes-1 clinical trial with angiographic, OCT and IVUS 6-month follow-up, illustrated no TLF and in-scaffold late lumen loss was $0.15 \pm 0.23 \mathrm{~mm}$ [93].

\section{Mirage BRMS}

Mirage Bioresorbable Micro-fiber Scaffold (Manli Cardiology Singapore) is a PLLA-based sirolimuseluting scaffold. Its strut thickness is either $125 \mu \mathrm{m}$ or $150 \mu \mathrm{m}$ if $3.5 \mathrm{~mm}$ or larger in diameter. Its scaffold has a helical coil design that provides high flexibility. Prospective, single-blinded, 1:1 randomized trial of Mirage to Absorb $(n=60)$ with 12-month follow-up demonstrated non-statistically significant difference of median in-scaffold late luminal loss of $0.37 \mathrm{~mm}$ (IQR: 0.08 to $0.72 \mathrm{~mm}$ ) and $0.23 \mathrm{~mm}$ (IQR: 0.15 to 0.37 $\mathrm{mm})$, respectively [94].

\section{Fantom and ReZolve}

The Fantom (Reva Medical Inc, San Diego, CA, USA) is a sirolimus-eluting scaffold with a strut thickness of $125 \mu \mathrm{m}$. The device is constructed from desaminotyrosine-derived polycarbonate material. Its characteristic features are complete scaffold visibility under X-ray, single-step continuous inflation and lower crossing profile $[95,96]$. In Fantom-I trial $(n=7)$, 4 months follow-up median in-stent lumen loss was $0.21 \mathrm{~mm}$. With IVUS, mean lumen area varied from $6.15 \pm 0.68 \mathrm{~mm}^{2}$ at post procedure to $5.6 \pm 0.67 \mathrm{~mm}^{2}$ at 4 months ( $\mathrm{p}=0.2$ ), with $3.1 \pm 2.0 \%$ of neointimal hyperplasia obstruction. Compared to OCT, the 4-month total neointimal hyperplasia area was $1.56 \pm 0.28 \mathrm{~mm}^{2}$ and $99.1 \%$ of all struts were covered with no incomplete strut apposition. No clinical events were observed up to 6 months of follow-up [97]. Fantom-II illustrated 6-month target vessel MI of $1.71 \%$ and mean late lumen loss of $0.29 \pm 0.38 \mathrm{~mm}$.

The ReZolve is the revision upon REVA scaffold, which has a spiral slide-and-lock mechanism and coated with sirolimus. In the RESTORE (ReZolve sirolimuseluting bioresorbable coronary scaffold) clinical trial, acute recoil was minimal at $3.8 \%$ and at 6 months there were $9 \%(n=2)$ focal in-scaffold TLRs [98].

\section{FADES Scaffold}

The FADES scaffold (Zorion Medical, Indianapolis, IN, USA) is a fully bioresorbable drug-eluting scaffold. The polymer of the scaffold involves a hybrid material of magnesium that includes rare earth elements and poly(lactic-co-glycolic-acid) (PLGA). Early studies illustrated that the device was completely absorbed with little to no inflammatory response within 60 days [99].

\section{Conclusions}

Our experience with Magnesium BRS was challenging visualization of stent post-deployment, which required road-map for post-dilatation due to less radio-opaque scaffold and small tantalum radio-opaque markers. Additionally, it was imperative for good lesion preparation with appropriate balloon type and diameter. Lesion selection was also crucial, as Magnesium BRS (Magmaris) only had diameters of $3.0 \mathrm{~mm}$ and $3.5 \mathrm{~mm}$. Meanwhile, there was good tractability of magnesium BRS, not dissimilar to metallic DES.

We demonstrated good procedural success and shortterm outcome in the use of Magnesium BRS in our Asian cohort. However, a larger cohort and long-term outcome monitoring would better delineate the safety and efficacy of this BRS. 
Executive summary

Background: Bioresorbable scaffold offer the advantages of reduced long-term complications such as stent fracture, late stent thrombosis and in-stent restenosis as well as the return of normal vasomotor function and late lumen gain with plaque regression.

Objective: Identify safety and outcomes of patients undergoing percutaneous coronary intervention (PCI) with magnesium BRS.

Materials and methods: This was a prospective, observational single centre study conducted in UiTM Sungai Buloh from 1st November 2016 to 14th February 2017.

Results: 7 patients were enrolled. The mean age was $46 \pm 9$. All patients were male. Ethnicity breakdown showed 5 Malays, 1 Chinese, and 1 Indian. Cardiovascular risk assessment revealed 85.7\% diabetes mellitus, 42.9\% smokers, 28.6\% hypertension and $28.6 \%$ dyslipidaemia. Target vessels treated were 6 left anterior descending (LAD) and 1 right coronary artery (RCA). Out of the 7 patients, $28.6 \%$ were type A lesions, $42.8 \%$ were type $B$, and $28.5 \%$ were type C. Among those lesions, 3 involved LAD-D1 bifurcations, and 2 were total occlusions. The lesions were prepared with semi-compliant balloons in 5 cases and non-compliant balloons in 2 cases. The balloon-to-stent ratios were 1:1 $(n=1), 0.92: 1(n=1), 0.85: 1(n=4)$ and 0.83:1 $(n=1)$. The magnesium BRS diameters used were $3.5 \mathrm{~mm}(n=4)$ and 3.0 $\mathrm{mm}(\mathrm{n}=3)$ with length of $15 \mathrm{~mm}(\mathrm{n}=1), 20 \mathrm{~mm}(\mathrm{n}=4)$ and $25 \mathrm{~mm}(\mathrm{n}=2)$. Post-dilatation in one patient was carried out with non-compliant balloon of equal diameter to the stent, while the rest had upsizing with $+0.5 \mathrm{~mm}$ larger noncompliant balloon. Procedural outcome was $100 \%$ successful. At three-month follow-up, there were no symptoms, MACE or TLR.

Conclusion: We demonstrated safety and good short-term outcome in the use of magnesium BRS in our cohort, including stenting of total occlusions as well as bifurcation lesions. A larger cohort and longer-term outcome would better delineate the safety and efficacy of this new technology in treating coronary artery disease.

\section{References}

1. Hulten E, Carlson DW. Invasive Coronary Angiography. Atheroscle: Clin. Persp. Imaging. 8: 77-98 (2012).

2. Shrager JB. The Vineberg procedure: the intermediate forerunner of coronary artery bypass grafting. Ann. Thorac. Surg. 57(5): 1354-1364 (1994).

3. Topaz, Pavlos S, Mackall JA, Nair R, Hsu J. The Vineberg procedure revisited: Angiographic evaluation and coronary artery bypass surgery in a patient 21 years following bilateral internal mammary artery implantation. Catheter. Cardiovascul. Interven. 25(3): 218-222 (1992).

4. Langenhove GV, Serrano P, Serruys PW. Long-term survival more than two decades after direct surgical myocardial revascularization. Intern. J. Cardiol. 73(1): 83-86 (2000).

5. Marx R, Jax TW, Kelm M, Schoebel FC, Strauer BE. Vineberg graft: flow reserve of bilateral implantation after 27 years. Ann. Thorac. Surg. 71(1): 341-343 (2001).

6. Tsung O, Cheng. First Selective Coronary Arteriogram. Circulation. 107(5): e42 (2003).

7. Thomas J, Ryan. The coronary angiogram and its seminal contribution to cardiovascular medicine over five decades. Circulation. 106: $752-756$ (2001).

8. Sones FM. Stormy petrel of cardiology. Clin. Cardiol. 17(7): 405-407 (1994).

9. Leimgruber P, Roubin GS, Hollman J, et al. Restenosis after successful coronary angioplasty in patients with single-vessel disease. Circulation. 73: 710-717 (1986).

10. Gruentzig AR, King SB, Schlumpf M, Siegenthaler W. Longterm follow-up after Percutaneous Transluminal Coronary Angioplasty. N. Engl. J. Med. 316: 1127-1132 (1987).
11. Bredlau CE, Roubin GS, Leimgruber PP, Douglas JS, King SB, Gruentzig AR. In-hospital morbidity and mortality in patients undergoing elective coronary angioplasty. Circulation. 72: 10441052 (1985).

12. Holmes DR, Vlietstra RE, Smith HC, et al. Restenosis after percutaneous transluminal coronary angioplasty (PTCA): A report from the PTCA registry of the national heart, lung and blood institute. Am. J. Cardiol. 53(12): C77-C81 (1984).

13. Serruys PW, Luijten $\mathrm{HE}$, Beatt $\mathrm{KJ}$, et al. Incidence of restenosis after successful coronary angioplasty: a time-related phenomenon. Circulation. 77(2): 361-371 (1988).

14. Serruys PW, Jaegere PD, Kiemeneij F, et al. A Comparison of Balloon-Expandable-Stent Implantation with Balloon Angioplasty in Patients with Coronary Artery Disease. N. Engl. J. Med. 331: 489-495 (1994).

15. Sigwart U, Puel J, MirkovitchV, Joffre F, Kappenberger L. Intravascular Stents to Prevent Occlusion and Re-Stenosis after Transluminal Angioplasty. N. Engl. J. Med. 316: 701-706 (1987).

16. Daemen J, Wenaweser P, Tsuchida K, et al. Early and late coronary stent thrombosis of sirolimus-eluting and paclitaxeleluting stents in routine clinical practice: data from a large twoinstitutional cohort study. Lancet. 369(9562): 667-678 (2007).

17. Serruys PW, Strauss BH, Beatt KJ, et al. Angiographic follow-up after placement of self-expanding coronary-artery stent. $N$. Engl. J. Med. 324: 13-17 (1991).

18. Puel J, Juilliere Y, Bertrand ME, et al. Early and late assessment of stenosis geometry after coronary arterial stenting. Am. J. Cardiol. 61: 546-553 (1988).

19. Reiber JHC, Serruys PW, Kooijman CJ, et al. Assessment of short-, medium-, and long-term variations in arterial dimension from computer-assisted quantification of coronary cineangiograms. Circulation. 71: 280-288 (1985). 
20. Marie-Claude M, Patrick WS, Eduardo S, et al. A Randomized Comparison of a Sirolimus-Eluting Stent with a Standard Stent for Coronary Revascularization. N. Engl. J. Med. 346: 1773-1780 (2002).

21. Ralf Z, Christian WH, Steffen S, et al. Incidence and Predictors of Target Vessel Revascularization and Clinical Event Rates of the Sirolimus-eluting Coronary Stent (Results from the Prospective Multicenter German Cypher Stent Registry). Am. J. Cardiol. 95(11): 1302-1308 (2005).

22. Sousa JE, Costa MA, Abizaid A, et al. Lack of neointimal proliferation after implantation of sirolimus-coated stents in human coronary arteries: a quantitative coronary angiography and three-dimensional intravascular ultrasound study. Circulation. 103: 192-195 (2001).

23. Suzuki T, Kopia G, Hayashi S, et al. Stent-based delivery of sirolimus reduces neointimal formation in a porcine coronary model. Circulation. 104: 1188-1193 (2001).

24. Friedrich WM, Marie-Claude M, Pieter K, et al. Coronary artery bypass graft surgery versus percutaneous coronary intervention in patients with three-vessel disease and left main coronary disease: 5-year follow-up of the randomised, clinical SYNTAX trial. Lancet. 381(9867): 629-638 (2013).

25. David PT. CABG or stents in coronary artery disease: end of the debate? Lancet. 381(9867): 605- 607 (2013).

26. Vasim F, David van K, Ewout WS, et al. Anatomical and clinical characteristics to guide decision making between coronary artery bypass surgery and percutaneous coronary intervention for individual patients; development and validation of SYNTAX score II. Lancet. 381: 639-650 (2013).

27. Hursh N, Anthony JW, Tarun C, et al. A Meta-Analysis of 3773 Patients Treated With Percutaneous Coronary Intervention or Surgery for Unprotected Left Main Coronary Artery Stenosis. J. Ame. Coll. Cardiol: Cardiovasc. Interven. 2(8): $739-747$ (2009).

28. Serruys PW, Andrew TLO, Lex A. et al. Five-Year Outcomes After Coronary Stenting Versus Bypass Surgery for the Treatment of Multivessel Disease: The Final Analysis of the Arterial Revascularization Therapies Study (ARTS) Randomized Trial. J. Ame. Coll. Cardiol. 46(4): 575-581 (2005).

29. Gregg WS, Jeffrey WM, Stephen GE, et al. Safety and Efficacy of Sirolimus- and Paclitaxel-Eluting Coronary Stents. N. Engl. J. Med. 356: 998-1008 (2007).

30. Michael J, Gaku N, Aloke VF, et al. Endothelial Cell Recovery Between Comparator Polymer-Based Drug-Eluting Stents. J. Ame. Coll. Cardiol. 52(5): 201 (2008).

31. Andrew F, Phillip FH, Sweta S, et al. Pathological Analysis of Local Delivery of Paclitaxel Via a Polymer-Coated Stent. Circulation. 104: 473-479 (2001).

32. Renu V, Francesco L, Goran S, et al. Mechanism of Late In-Stent After Implantation of A Paclitaxel Derivate-Eluting Polymer Stent System in Humans. Circulation. 106: 2649-2651 (2002).

33. Norio T, Renu V, Gordon G, et al. Polymer-Free Biolimus A9Coated Stent Demonstrates More Sustained Initmal Inhibition, Improved Healing, and Reduced Inflammation Compared With a Polymer-Coated Sirolimus-Eluting Cyper Stent in a Porcine Model. Circulation: Cardiovascul. Interven. 3: 174-183 (2010).

34. Lakshmana KP, Jinsheng L, Toshiro S, et al. EndotheliumDependent Vasomotor Dysfunction in Pig Coronary Arteries
With Paclitaxel-Eluting Stents Is Associated With Inflammation and Oxidative Stress. J. Ame. Coll. Cardiol. 2(3): 253-262 (2009).

35. Michalis IH, Miodrag O, Branko B, et al. Differential Effects of Drug-Eluting Stents on Local Endothelium-Dependent Coronary Vasomotion. J. Ame. Coll. Cardiol. 51(22): 2123-2129 (2008).

36. Jinsheng L, Refat J, Lakshmana P, et al. Abnormal Vasomotor Function of Porcine Coronary Arteries Distal to SirolimusEluting Stents. J. Am. Coll. Cardiol: Cardiol. Interven. 1(3): 279285 (2008).

37. Soichiro F, Kiyoaki M, Kenji K, et al. Impaired Endothelial Vasomotor Function After Sirolimus-Eluting Stent Implantation. Circulation. J: Jap. Circulation. Society. 71: 220-225 (2007).

38. Jyun-ei O, Yoshinobu K, Hajime T, et al. Sirolimus-Eluting Stent Implantation Aggravates Endothelial Vasomotor Dysfunction in the Infarct-Related Coronary Artery in Patients With Acute Myocardial Infarction. J. Am. Coll. Cardiol. 50(14): 1305-1309 (2007).

39. Patrick WS, Hector MG, Yoshinobu O. From metallic cages to transient bioresorbable scaffolds: change in paradigm of coronary revascularization in the upcoming decade? Euro. Heart. J. 33(1): $16-25$ (2012).

40. Hoppmann, Kufner, Cassese, et al. Angiographic and clinical outcomes of patients treated with everolimus-eluting bioresorbable stents in routine clnical practice: Results of the ISAR-ABSORB registry. Catheter. Cardiovascul. Interven. 87(5): 822-829.

41. Gregg WS, Runlin G, Takeshi K, et al. 1-year outcomes with the Absorb bioresorbable scaffold in patients with coronary artery disease: a patient-level, pooled meta-analysis. Lancet. 387: 12771289 (2016).

42. Patrick WS, Bernard C, Yohei S, et al. Comparison of an everolimus-eluting bioresorbable scaffold with an everolimuseluting metallic stent for the treatment of coronary artery stenosis (ABSORB II): a 3 year, randomised, controlled, singleblind, multicentre clinical trial. Lancet. 388: 2479-2491 (2016).

43. Nicolas F, Alessio M, Philip W, Carlo DM. Bioresorbable Scaffold Thrombosis Why BRS Size Matters. J. Am. Coll. Cardiol. 68(5): 569-575 (2016).

44. Sabato S, Salvatore DR, Giuseppe A, et al. The duration of balloon inflation affects the luminal diameter of coronary segments after bioresorbable vascular scaffolds deployment. BMC. Cardiovasc. Disord. 15: 169 (2015).

45. Waksman R, Zumstein P, Pritsch M, et al. Second-generation Magnesium Scaffold Magmaris, Device Design, and Preclinical Evaluation in a Porcine Coronary Artery Model. Eurointervention. 8: 25 (2017).

46. Fajadet J, Haude M, Joner M, et al. Magmaris preliminary recommendation upon commercial launch: a consensus from the expert panel on 14 April 2016. Eurointervention. 12(7): 828833 (2016).

47. Ron W. Bioresorbable scaffolds are here, please handle with care. Cardiovascul. Revascular. Med. 17(6): 353-354 (2016).

48. Yohei S, Yoshinobu O, Carlos C, et al. Bioresorbable Scaffold The Emerging Reality and Future Directions. Circulation. Resear. 120: 1341- 1352 (2017).

49. Nicolas F, Jaryl N, Philip W, Carlo DM. Current bioresorbable 
scaffold technologies for treatment of coronary artery diseases: Do polymer and Magnesium platforms differ? Inter. J. Cardiol. 223: 526-528 (2016).

50. David P, Faxon. The Biosolve II Trial: a step forward for bioresorbable scaffold? Euro. Heart. J. 37(35): 2710-2712 (2016).

51. Michael H, Huseyin I, Alexandre A, et al. Sustained safety and performance of the second generation drug-eluting absorbable metal scaffold in patients with de novo coronary lesions: 12-month clinical results and angiographic findings of the BIOSOLVE-II first-in-man trial. Euro. Heart. J. 37(35): 27012709 (2016).

52. Wittchow E, Adden N, Riedmuller J, Savard C, Waksman $\mathrm{R}$, Braune M. Bioresorbable drug-eluting magnesium- alloy scaffold: design and feasibility in a porcine coronary model. Eurointervention. 8: 1441-1450 (2013).

53. Haude M, Erbel R, Erne P, et al. Safety and performance of the Drug-eluting Absorbable Metal Scaffold (DREAMS) in patients with de novo coronary lesions: 3-year results of prospective, multi-centre, first-in-man BIOSOLVE-1 trial. Eurointervention. 12(2): e160-166 (2016).

54. Karjalainen P, Paana T, Sia J, Nammas W. Neointimal Healing Evaluated by Optical Coherence Tomography after Drug-Eluting Absorbable Metal Scaffold Implantation in de novo Native Coronary Lesions: Rationale and Design of the Magmaris-OCT Study. Cardiol. 137: 225-230 (2017).

55. Wan Azman WA, Kui-Hian. Annual Report of the National Cardiovascular Disease (NCVS)-Acute Coronary Syndrome (ACS) 2011-2013. Nat. Heart. Assoc. Malaysia. Minis. Heal. Malaysia. (2015).

56. Michael H, Raimund E, Paul E, et al. Safety and performance of the drug-eluting absorbable metal scaffold (DREAMS) in patients with de-novo coronary lesions: 12 month results of the prospective, multicentre, first-in-man BIOSOLVE-I trial. Lancet. 381(9869): 836-844 (2013).

57. Yuri BP, Donald EC. Disappearing stents-DREAMS of a sorcerer's apprentice? Lancet. 381(9869): 787-789 (2013).

58. Michael H, Raimund E, Paul E, et al. Safety and performance of the DRug-Eluting Absorbable Metal Scaffold (DREAMS) in patients with de novo coronary lesions: 3-year results of the prospective, multicentre, first-in-man BIOSOLVE-I trial. EuroIntervention. 12(2): e160-166 (2016).

59. Waksman R, Zumstein P, Pritsch M, et al. Second-generation Magnesium Scaffold Magmaris, Device Design, and Preclinical Evaluation in a Porcine Coronary Artery Model. Eurointervention. 8:45 (2017).

60. David P. Faxon. The Biosolve II Trial: a step forward for bioresorbable scaffold? Euro. Heart. J. 37(35): 2710-2712 (2016).

61. Michael H, Huseyin I, Alexandre A, et al. Sustained safety and performance of the second generation drug-eluting absorbable metal scaffold in patients with de novo coronary lesions: 12-month clinical results and angiographic findings of the BIOSOLVE-II first-in-man trial. Euro. Heart. J. 37(35): 2701-2709 (2016).

62. Haude M, Erbel R, Erne P, et al. Safety and performance of the Drug-eluting Absorbable Metal Scaffold (DREAMS) in patients with de novo coronary lesions: 3-year results of prospective, multi-centre, first-in-man BIOSOLVE-1 trial. Eurointervention. 12(2): e160-166 (2016).

63. Warren ECW, Aftred FP. Magnesium Metabolism. N. Engl. J. Med. 278: 658-663 (1968).

64. Blaine. Metabolism. Clin. J. Ame. Society. Nephrol. 10(7): 1257$1272(2015)$.

65. De B. De novo coronary lesions. Physiol. Rev. 95(1): 1-46 (2015).

66. Peter B, Jun T, Carlo DM. Coronary bioabsorbable magnesium stent: 15 -month intravascular ultrasound and optical coherence tomography findings. Eur. Heart. J. 28 (19): 2319 (2007).

67. Bella TA, Burton MA. Endothelium-dependent relaxation in coronary arteries require magnesium ions. Br. J. Pharmacol. 91(3): 449-451 (1987).

68. Gold ME, Buga GM, Wood KS, Byrns RE, Chaudhuri G, Ignarro LJ. Antagonisitc modulatory roles of magnesium and calcium on release of endothelium-derived relaxing factor and smooth muscle tone. Circulation. Resear. 66: 355-366 (1990).

69. Paul JP, Paulo RB, John FS, Hartzell. Hypomagnesemia Inhibits Nitric Oxide Release from Coronary Endothelium: Protective Role of Magnesium Infusion after Cardiac Operations. Ann. Thoracic. Surg. 65(4): 967-972 (1998).

70. Keith WM, Kennedy RL. A Randomized, Double-Blind, Placebo-Controlled Pilot Trial of Intravenous Magnesium Sulfate in Acute Stroke. Stroke. 26(7): 1183-1188 (1995).

71. Michael S, Michael S, Maura JP, et al. Oral Magnesium Therapy Improves Endothelial Function in Patients with Coronary Artery Disease. Circulation. 102: 2353-2358 (2000).

72. Sabato S, Salvatore R, Giuseppe A, et al. The duration of balloon inflation affects the luminal diameter of coronary segments after bioresorbable vascular scaffolds deployment. BMC. Cardiovasc. Disord. 15: 169 (2015).

73. Wolfram S, Peter B, Christoph BW, Stefan S, Niels G, KlausPeter S. In vitro performance investigation of bioresorbable scaffolds - Standard tests for vascular stents and beyond. Cardiovascul. Revascular. Med. 7(6): 375-383 (2016).

74. Jens W, Holger MN, Christian W. Current Status of Bioresorbable Scaffold in the Treatment of Coronary Artery Disease. J. Am. Coll. Cardiol. 64(23): 2541-2551 (2014).

75. Christos VB, Yoshinobu O, Vasim F, et al. Bioresorbable scaffolds: Current knowledge, potentialities and limitations experienced during their first clinical applications. Intern. J. Cardiol. 167(1): 11-21 (2013).

76. Kocka V, Martin M, Petr T, et al. Bioresorbable vascular scaffolds in acute ST-segment elevation myocardial infarction: a prospective multicentre study 'Prague 19'. Euro. Heart. J. 35(12): 787-794 (2014).

77. Leigh P, Mary BK, Julia CF, Richard JR. Paving the way to a bioresorbable technology: Development of the absorb BRS program. Catheter. Cardiovascul. Interven. 88(S1): 1-9 (2016).

78. Heublein B, Rohde R, Kaese V, Niemeyer M, Hartung W, Haverich A. Biocorrosion of magnesium alloys: A new principle in cardiovascular implant technology? Heart. 89(6): 651-666 (2003).

79. Waksman R, Pakala R, Kuchulakanti PK, et al. Safety and efficacy 
of bioabsorbable magnesium alloy stents in porcine coronary arteries. Catheter. Cardiovascul. Interven. 68(4): 607-617 (2006).

80. Waksman R. Long-term clinical data of the BIOSOLVE-I study with the paclitaxel-eluting absorbable magnesium scaffold (DREAMS 1st generation) and multimodality imaging analysis. Euro. PCR. 8:32 (2014).

81. Erbel R, Di Mario C, Bartunek J, et al. Temporary scaffolding of coronary arteries with bioabsorbable magnesium stents: A prospective, non-randomised multicentre trial. Lancet. 369(9576): 1869-1875 (2007).

82. Ghimire G, Spiro J, Kharbanda R, et al. Initial evidence of return of coronary vasoreactivity following the absorption of bioabsorbable magnesium alloy coronary stents. Eurointervention. 4(4): 481-484 (2009).

83. Barlis P, Tanigawa J, Di Mario C. Coronary bioabsorable magnesium stent: 15-month intravascular ultrasound and optical coherence tomography findings. Euro. Heart. J. 28(19): 2319 (2007).

84. Carlo di M, Huw G, Omer G, et al. Drug-Eluting Bioabsorbable Magnesium Stent. J. Interven. Cardiol. 16(6): 391-395 (2004).

85. Soji N, Kunihiko K, Keiji I, et al. Long-Term (>10 Years) Clinical Outcomes of First-in-Human Biodegradable Poly-1Lactic Acid Coronary Stents Igaki-Tamai Stents. Circulation. 125: 2343-2352 (2012).

86. Costa JD, Abizaid A, Ormiston JA, et al. Six-month IVUS analysis of the DESolve FIM trial with novel PLLA-based fully biodegradable drug-eluting scaffold. Euro. Heart. J. 34: 3039 (2013).

87. Alexandre A, Ricardo AC, Joachim S, et al. Serial Multimodality Imaging and 2-Year Clinical Outcomes of the Novel DESolve Novolimus-Eluting Bioresorbable Coronary Scaffold System for the Treatment of Single De Novo Coronary Lesions. J. Am. Coll. Cardiol. Intv. 9: 565-574 (2016).

88. Davide C. Bioresorbable Scaffolds: Clinical Outcomes and Considerations. Interven. Cardiol. Clin. 5(3): 357-363 (2016).

89. Carlos MC, Pannipa S, Shimpei N, Yoshinobu O, Patrick WS,
Hector M. Short- and Long-term Evaluation of Bioresorbable Scaffolds by Optical Coherence Tomography. Interven. Cardiol. Clin. 4(3): 333-349 (2015).

90. Sundeep M. A fresh look at bioresorbable scaffold technology: Intuition pumps. Ind. Heart. J. 69(1): 107-111 (2017)

91. Yanping C, Pawel G, Masahiko S, et al. Comparative Characterization of Biomechanical Behavior and Healing Profile of a Novel Ultra-High-Molecular-Weight Amorphous Poly-LLactic Acid Sirolimus-Eluting Bioresorbable Coronary Scaffold. Circulation: Cardiovascul. Interven. 9: e004253 (2016).

92. Colombo AA. Technology description and clinical experience. BRS: Clin. Case. Rev. 8: 16 (2016).

93. Seth A, Onuma Y, Costa R, et al. First-in-human evaluation of a novel poly-L-lactide based sirolimus-eluting bioresorbable vascular scaffold for the treatment of de novo native coronary artery lesions: MeRes-1 trial. EuroIntervention. $7: 8$ (2017).

94. Tenekecioglu E, Serruys PW, Onuma Y, et al. Randomized Comparison of Absorb Bioresorbable Vascular Scaffold and Mirage Microfiber Sirolimus-Eluting Scaffold Using Multimodality Imaging. JACC. Cardiovasc. Interv. 10(11): 1115-1130 (2017).

95. Costa R. Planned and ongoing clinical trials: A status update from the Cardiovascular Research Center (CRC). New bioresorbable scaffolds programmes: REVA and MIRAGE. EuroPCR. 10: 8 (2014).

96. Abizaid A. Other bioresorbable scaffold materials tyrosine polycarbonate. EuroPCR. 11: 9 (2014)

97. Costa, Ribamar J, Abizaid A, et al. Initial Results of the Fantom 1 Trial: A first-in-man evaluation of a novel, radiopaque sirolimuseluting bioresorbable vascular scaffold. J. Am. Coll. Cardiol. 67(13): 232 (2016)

98. Abizaid A, Brachmann, Johannes C, et al. TCT-39 12-Month Angiographic and Clinical Results of the ReZolve(r) SirolimusEluting Bioresorbable Coronary Scaffold: The RESTORE trial. J. Am. Coll. Cardiol. 62(18): B13 (2013).

99. Zhang Y, Bourantas CV, Farooq V, et al. Bioresorbable scaffolds in the treatment of coronary artery disease. Med. Dev. 6: 37-48 (2013). 